\title{
Sporting participation following the operative management of chondral defects of the knee at mid-term follow up: a systematic review and meta-analysis
}

\author{
P. G. Robinson ${ }^{1 *}$ (D, T. Williamson ${ }^{2}$, I. R. Murray ${ }^{1}$, K. Al-Hourani ${ }^{1}$ and T. O. White
}

\begin{abstract}
Purpose: The purpose of this study was to perform a systematic review of the reparticipation in sport at mid-term follow up in athletes who underwent biologic treatment of chondral defects in the knee and compare the rates amongst different biologic procedures.

Methods: A search of PubMed/Medline and Embase was performed in May 2020 in keeping with Preferred Reporting Items for Systematic Review and Meta-Analysis (PRISMA) guidelines. The criteria for inclusion were observational, published research articles studying the outcomes and rates of participation in sport following biologic treatments of the knee with a minimum mean/median follow up of 5 years. Interventions included microfracture, osteochondral autograft transfer (OAT), autologous chondrocyte implantation (ACl), matrix-induced autologous chondrocyte implantation (MACl), osteochondral allograft, or platelet rich plasma (PRP) and peripheral blood stem cells (PBSC). A random effects model of head-to-head evidence was used to determine rates of sporting participation following each intervention.

Results: There were twenty-nine studies which met the inclusion criteria with a total of 1276 patients (67\% male, $33 \%$ female). The mean age was 32.8 years (13-69, SD 5.7) and the mean follow up was 89 months (SD 42.4). The number of studies reporting OAT was 8 (27.6\%), ACI was 6 (20.7\%), MACI was 7 (24.1\%), microfracture was 5 (17.2\%), osteochondral allograft was 4 (13.8\%), and one study (3.4\%) reported on PRP and PBSC. The overall return to any level of sport was $80 \%$, with $58.6 \%$ returning to preinjury levels. PRP and PBSC (100\%) and OAT (84.4\%) had the highest rates of sporting participation, followed by allograft (83.9\%) and $\mathrm{ACl}(80.7 \%)$. The lowest rates of participation were seen following MACI (74\%) and microfracture (64.2\%).

Conclusions: High rates of re-participation in sport are sustained for at least 5 years following biologic intervention for chondral injuries in the knee. Where possible, OAT should be considered as the treatment of choice when prolonged participation in sport is a priority for patients. However, MACl may achieve the highest probability of returning to the same pre-injury sporting level.

Level of evidence: IV
\end{abstract}

Keywords: Biologics, Regeneration, Repair, Chondrocyte, Athlete

* Correspondence: Patrick.robinson321@gmail.com

${ }^{1}$ Edinburgh Orthopaedics, Royal Infirmary of Edinburgh, Edinburgh, Scotland

Full list of author information is available at the end of the article

(0) The Author(s). 2020 Open Access This article is licensed under a Creative Commons Attribution 4.0 International License, which permits use, sharing, adaptation, distribution and reproduction in any medium or format, as long as you give appropriate credit to the original author(s) and the source, provide a link to the Creative Commons licence, and indicate if changes were made. The images or other third party material in this article are included in the article's Creative Commons licence, unless indicated otherwise in a credit line to the material. If material is not included in the article's Creative Commons licence and your intended use is not permitted by statutory regulation or exceeds the permitted use, you will need to obtain permission directly from the copyright holder. To view a copy of this licence, visit http://creativecommons.org/licenses/by/4.0/. 


\section{Background}

Chondral defects in the knee are problematic for athletes primarily as a consequence of 1) focal defects having intrinsically a poor ability to heal and 2) the early development of symptomatic arthritis. These injuries are reported to be $20 \%$ more common in athletes compared to the general population [2] and can lead to lifestyle modification (such as ceasing sporting participation) due to pain and loss of function. Therefore, it is imperative that tailored and effective treatment options are offered to these patients. Ideally, such treatments will preserve the integrity of the native knee and return the patient to their pre-injury performance level within an acceptable timeframe. Patients most at risk of chondral injuries include those with a higher body mass index (BMI) or who have previously had an anterior cruciate ligament (ACL) injury $[1,15]$. Chondral injury has been reported to present in up to $50 \%$ of patients undergoing ACL reconstructive surgery $[4,6]$.

The current treatment options available for the management of focal chondral defects include microfracture, autologous chondrocyte implantation (ACI), matrixinduced autologous chondrogenesis (MACI), osteochondral autograft/allograft implantation and injectable cellbased therapies. Two previous meta-analyses and a systematic review have analysed the rates of return to sport (RTS) following surgical management of articular knee defects with a range from $65 \%$ to $78 \%$ at mean follow up of 42 and 47 months respectively [19, 24]. Although RTS is considered one of the most important outcome measures for athletes following injury, there is little summarised information regarding the sustained rate of participation in sport following biologic interventions for the knee.

The purpose of this study was to perform a systematic review of the mid-term outcomes and rates of reparticipation in sport in athletes who underwent biologic intervention of chondral knee defects.

\section{Methods}

A search of PubMed/Medline and Embase was performed in May 2020 in line with the Preferred Reporting Items for Systematic Review and Meta-Analysis (PRIS MA) guidelines. The study was registered using the PROSPERO International prospective register of systematic reviews. The search terms used were: 'knee AND (chondral OR chondrocyte OR osteochondral or cartilage) AND (allograft OR autograft OR autologous OR implantation OR transplantation OR mosaicplasty OR OAT OR OATS OR microfracture OR MACI OR ACI OR platelet OR plasma OR mesenchymal OR stem OR BMAC OR bone marrow OR concentrate) AND (sport OR athlete)'.
Inclusion criteria were research articles studying the use of biologic techniques to repair or regenerate knee cartilage in athletes. Studies were included if the mean or median follow up was a minimum of 5 years. Studies were excluded if they had a mean/median follow up of less than 5 years, did not report on postoperative return to sport rates, were review articles, editorials/letters to the editor, or were not published in the English language.

Titles and abstracts identified were independently reviewed by two authors (P.G.R., T.R.W) and those not meeting the inclusion criteria were excluded prior to full text review. Full text studies were further evaluated against the inclusion and exclusion criteria. The references of the included papers were also reviewed to ensure no relevant studies were missed. The search process is presented in Fig. 1.

The year of publication, age, gender, BMI, size of chondral lesion, lesion location, type of biologic, rate of return to sport, time to return, level of participation and postoperative patient reported outcome measures were recorded, if available, for each study.

\section{Outcome measures}

Our primary outcome was the rate of reparticipation in sport in athletes undergoing biologic knee surgery at mid-term follow up. Secondary outcomes included comparing the time to RTS, level of sport the athlete returned to and patient reported outcome measure scores (PROMS) at mid-term follow up. A meta-analysis of the primary outcome by each biologic intervention was performed if the studies were sufficiently homogenous.

\section{Quality assessment}

All studies were assessed for quality by two authors (P.G.R., T.W.) using the National Institute of Health Quality Assessment Tool for Observational Cohort and Cross-Sectional Studies. The assessment tool uses 14 questions to enable allocation of a score to each article (poor, fair or good). If there was disagreement regarding the scoring of a study, consensus will be met after discussion amongst both assessors.

\section{Statistical analysis}

Statistical analysis was performed using Statistical Package for Social Sciences (SPSS) software (IBM, Inc., Armonk, New York, United States) v24. Data were tested for parametricity using Kolmogorov-Smirnov testing. Continuous variables were reported by means and standard deviations and compared using the student $\mathrm{T}$ test and categorical data was compared the using chisquared test. Nonparametric tests (Kruskal-Wallis and Mann-Whitney $U$ tests) were used to assess for 


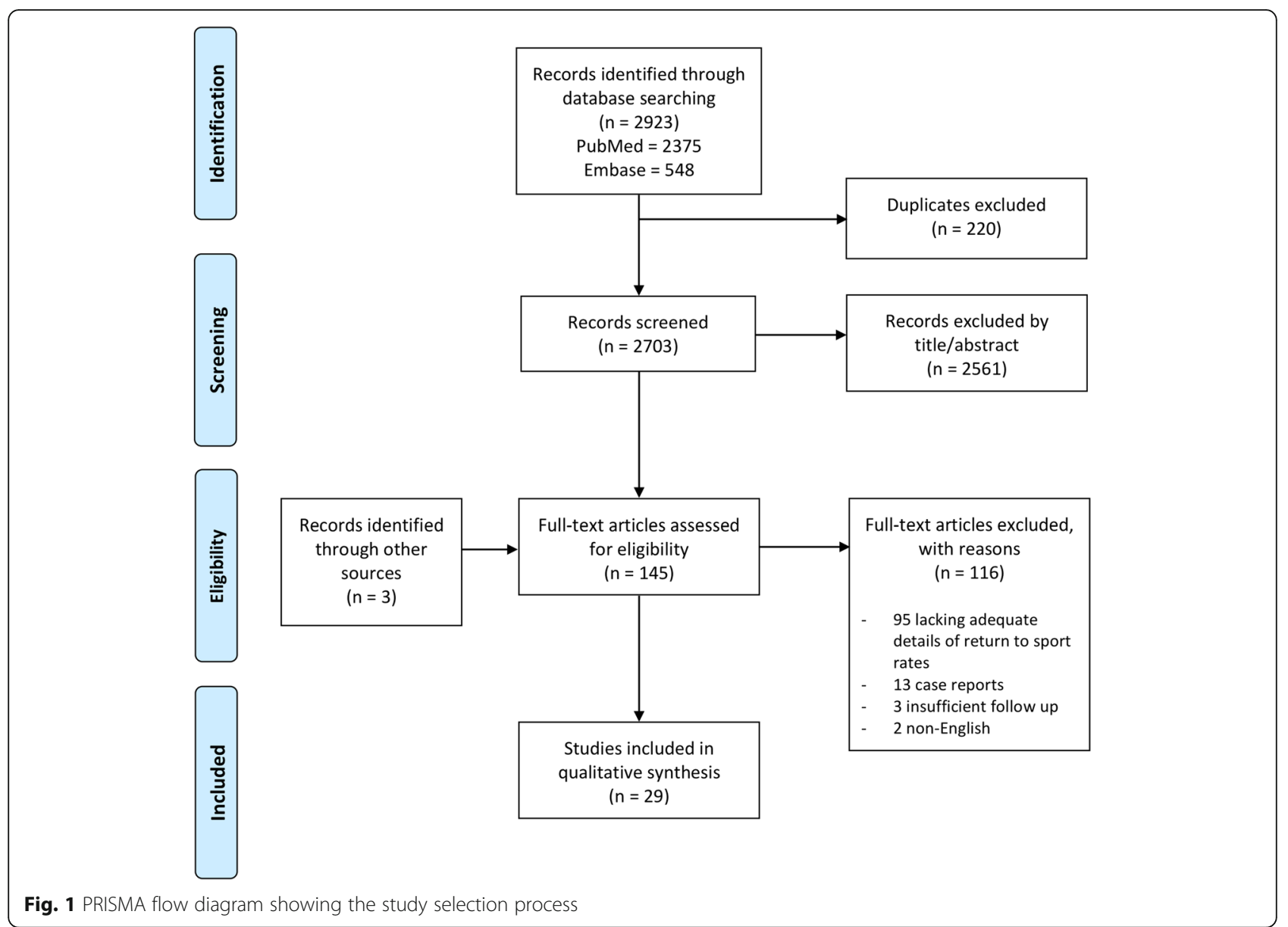

differences in sporting participation rates between interventions. Correlation between continuous variables and rates of sporting participation were assessed using Pearson's coefficient. Heterogeneity between studies was tested using preoperative parameters of age, BMI, lesion size and preoperative outcome measure score using $I^{2}$ index based on Cochran's $\mathrm{Q}$ with an $I^{2}$ index greater than 50\% deemed heterogenous. Random effects modelling was used to measure effect size of the type of biologic and rate of participation in sport. The data was standardised to means and standard deviations (SDs), weighted for sample size.

\section{Results}

There were 2703 articles identified in the initial search of databases. After initial screening of titles and abstracts, 142 articles met the inclusion criteria for review. On full text screening, a further 113 studies were excluded as they met the exclusion criteria (Fig. 1). There were twenty-nine studies which met the inclusion criteria (Table 1). The year of publication ranged from 2004 to 2019 . There were 24 case series, two prospective cohort studies, 2 randomised controlled trials and one case-control study. There were a total of 1276 patients included across all studies. The mean age was 32.8 years $( \pm 5.7)$ and $67 \%$ were males and $33 \%$ females. The mean length of follow up was 88.8 months $( \pm 42.4)$. Patient demographics can be seen in Table 2.

\section{Quality assessment}

The results of the quality assessment of included studies can be seen in Appendix 1. The overall mean percentage of successfully answered questions from the assessment tool was $61.1 \%$ (range $42.9 \%$ to $85.7 \%$ ). Two studies were level one, two were level two, one was level three, and twenty-four were level four.

\section{Return to sport}

The overall rate of patients participating in sport at any level was $80.0 \%$ (Fig. 2). Sporting participation following microfracture was $64.2 \%$, MACI was $74.0 \%$, ACI was $80.7 \%$, Osteochondral allograft was $83.9 \%$, OAT was $84.4 \%$, and PRP and PBSC was $100 \%(p<0.001)$. There were sixteen studies which reported on the rate of returning to preinjury sports levels, with $58.6 \%$ returning to their preinjury performance. Rates of return to preinjury levels of sport were highest following MACI 
Table 1 Patient demographics and outcome measures of included studies

\begin{tabular}{|c|c|c|c|c|c|c|c|c|}
\hline Study & Journal & Year & LOE & $\begin{array}{l}\text { No. of } \\
\text { patients }\end{array}$ & Gender & Mean age (range) & $\begin{array}{l}\text { Follow up } \\
\text { (months) }\end{array}$ & Outcome measures \\
\hline Cotter et al. [3] & Arthroscopy & 2018 & IV & 22 & NR & 24.39 (NR) & 87 & RTS \\
\hline Ebert et al. [7] & $\begin{array}{l}\text { American Journal of } \\
\text { Sports Medicine }\end{array}$ & 2015 & IV & 31 & $15 \mathrm{M}, 16 \mathrm{~F}$ & $35.3(16-57)$ & 60 & $\begin{array}{l}\text { RTS, KOOS, Lysholm, } \\
\text { Tegner, SF-36 }\end{array}$ \\
\hline Ebert et al. [8] & $\begin{array}{l}\text { American Journal of } \\
\text { Sports Medicine }\end{array}$ & 2012 & । & 63 & $42 \mathrm{M}, 21 \mathrm{~F}$ & $38.2(16-63)$ & 60 & RTS, KOOS, SF-36 \\
\hline Ebert et al. [9] & $\begin{array}{l}\text { American Journal of } \\
\text { Sports Medicine }\end{array}$ & 2011 & IV & 41 & $21 \mathrm{M}, 20 \mathrm{~F}$ & $38.5(13-65)$ & 60 & RTS, KOOS, SF-36 \\
\hline Ebert et al. [10] & $\begin{array}{l}\text { Orthopaedic Journal } \\
\text { of Sports Medicine }\end{array}$ & 2019 & III & 97 & $60 \mathrm{M}, 37 \mathrm{~F}$ & $36.8(15-62)$ & 60 & RTS, KOOS \\
\hline Gillogly et al. [11] & $\begin{array}{l}\text { American Journal of } \\
\text { Sports Medicine }\end{array}$ & 2014 & IV & 23 & $11 \mathrm{M}, 12 \mathrm{~F}$ & 31 (NR) & 91 & $\begin{array}{l}\text { RTS, IKDC, Modified } \\
\text { Cincinnati, Lysholm, SF-12 }\end{array}$ \\
\hline Gobbi et al. [12] & $\begin{array}{l}\text { Knee Surgery Sports } \\
\text { Traumatology \& } \\
\text { Arthroscopy }\end{array}$ & 2014 & IV & 61 & $43 \mathrm{M}, 18 \mathrm{~F}$ & 31.4 (NR) & 181 & RTS, IKDC, Lysholm, Tegner \\
\hline Gobbi et al. [13] & $\begin{array}{l}\text { Knee Surgery Sports } \\
\text { Traumatology \& } \\
\text { Arthroscopy }\end{array}$ & 2005 & IV & 53 & $38 \mathrm{M}, 33 \mathrm{~F}$ & $38(19-55)$ & 72 & RTS, IKDC, Lysholm, Tegner \\
\hline Gudas et al. [14] & $\begin{array}{l}\text { American Journal of } \\
\text { Sports Medicine }\end{array}$ & 2012 & । & 57 & $36 \mathrm{M}, 21 \mathrm{~F}$ & $24.3(15-40)$ & 125 & RTS, ICRS, Tegner \\
\hline Kon et al. [16] & $\begin{array}{l}\text { American Journal of } \\
\text { Sports Medicine }\end{array}$ & 2011 & $\|$ & 21 & $21 \mathrm{M}$ & $23.7(16-37)$ & 94 & RTS, IKDC, EQ-VAS, \\
\hline Kon et al. [18] & $\begin{array}{l}\text { American Journal of } \\
\text { Sports Medicine }\end{array}$ & 2009 & $\|$ & 80 & $60 \mathrm{M}, 20 \mathrm{~F}$ & $29.8(N R)$ & 60 & RTS, IKDC, ICRS, Tegner \\
\hline Liu et al. [20] & Arthroscopy & 2019 & IV & 13 & NR & $N R$ & 112 & RTS, Marx \\
\hline Marcacci et al. [21] & $\begin{array}{l}\text { American Journal of } \\
\text { Sports Medicine }\end{array}$ & 2007 & IV & 30 & $22 \mathrm{M}, 8 \mathrm{~F}$ & $29.3(17-46)$ & 84 & RTS, IKDC, ICRS, Tegner \\
\hline McCarthy et al. [22] & Arthroscopy & 2017 & IV & 13 & $7 \mathrm{M}, 6 \mathrm{~F}$ & $19.2(15.4-26.1)$ & 71 & $\begin{array}{l}\text { RTS, IKDC, KOOS, WOMAC, } \\
\text { SF-12, Marx, Tegner }\end{array}$ \\
\hline Minzlaff et al. [23] & $\begin{array}{l}\text { Knee Surgery Sports } \\
\text { Traumatology \& } \\
\text { Arthroscopy }\end{array}$ & 2016 & IV & 30 & NR & $31(19-39)$ & 83 & $\begin{array}{l}\text { RTS, Activity rating scale, } \\
\text { Tegner }\end{array}$ \\
\hline Monckeberg et al. [25] & Knee & 2019 & IV & 20 & $13 \mathrm{M}, 7 \mathrm{~F}$ & $32.7(21-47)$ & 60 & RTS, IKDC \\
\hline Nielsen et al. [26] & $\begin{array}{l}\text { American Journal of } \\
\text { Sports Medicine }\end{array}$ & 2017 & IV & 149 & $87 \mathrm{M}, 62 \mathrm{~F}$ & $31.2(N R)$ & 72 & $\begin{array}{l}\text { RTS, Merle d'Aubigne'-Postel } \\
\text { score, IKDC, Knee Society } \\
\text { Function Score }\end{array}$ \\
\hline Ollat et al. [27] & $\begin{array}{l}\text { Orthopaedics \& } \\
\text { Traumatology: Surgery } \\
\text { \& Research }\end{array}$ & 2011 & IV & 20 & NR & $N R$ & 96 & RTS \\
\hline Panics et al. [28] & Cartilage & 2012 & IV & 61 & $55 \mathrm{M}, 6 \mathrm{~F}$ & $25.2(16-41)$ & 115 & $\begin{array}{l}\text { RTS, ICRS, HSS, Mod- } \\
\text { Cincinnati, Lysholm }\end{array}$ \\
\hline Pelissier et al. [29] & $\begin{array}{l}\text { Knee Surgery Sports } \\
\text { Traumatology \& } \\
\text { Arthroscopy }\end{array}$ & 2014 & IV & 12 & $10 \mathrm{M}, 2 \mathrm{~F}$ & 29 (NR) & 120 & RTS, IKDC, Lysholm \\
\hline Pestka et al. [30] & $\begin{array}{l}\text { American Journal of } \\
\text { Sports Medicine }\end{array}$ & 2016 & IV & 130 & $81 \mathrm{M}, 49 \mathrm{~F}$ & $36.2(14.8-52.9)$ & 64 & RTS, Tegner \\
\hline Ronga et al. [31] & Joints & 2015 & IV & 4 & $3 \mathrm{M}, 1 \mathrm{~F}$ & $21.2(18-24)$ & 126 & $\begin{array}{l}\text { RTS, Mod Cincinnati, } \\
\text { Lysholm, Tegner }\end{array}$ \\
\hline Scillia et al. [32] & $\begin{array}{l}\text { American Journal of } \\
\text { Sports Medicine }\end{array}$ & 2015 & IV & 18 & $18 \mathrm{M}$ & NR & 71 & RTS \\
\hline Stone et al. [33] & $\begin{array}{l}\text { Knee Surgery Sports } \\
\text { Traumatology \& } \\
\text { Arthroscopy }\end{array}$ & 2017 & IV & 74 & $46 \mathrm{M}, 28 \mathrm{~F}$ & $45.3(13-69)$ & 202 & RTS, IKDC, WOMAC, Tegner \\
\hline Tetta et al. [34] & $\begin{array}{l}\text { European Journal of } \\
\text { Radiology }\end{array}$ & 2010 & IV & 24 & $17 \mathrm{M}, 7 \mathrm{~F}$ & 29.9 (NR) & 113 & RTS, IKDC, Tegner \\
\hline
\end{tabular}


Table 1 Patient demographics and outcome measures of included studies (Continued)

\begin{tabular}{|c|c|c|c|c|c|c|c|c|}
\hline Study & Journal & Year & LOE & $\begin{array}{l}\text { No. of } \\
\text { patients }\end{array}$ & Gender & Mean age (range) & $\begin{array}{l}\text { Follow up } \\
\text { (months) }\end{array}$ & Outcome measures \\
\hline Vijayan et al. [35] & $\begin{array}{l}\text { The Journal of Bone } \\
\text { and joint Surgery (British) }\end{array}$ & 2012 & IV & 14 & $12 \mathrm{M}, 2 \mathrm{~F}$ & $23.6(16-40)$ & 62 & $\begin{array}{l}\text { RTS, Mod-Cincinnati, } \\
\text { Stanmore-Bentley }\end{array}$ \\
\hline Viste et al. [36] & $\begin{array}{l}\text { Orthopaedics \& } \\
\text { Traumatology: Surgery } \\
\text { \& Research }\end{array}$ & 2012 & IV & 14 & $7 \mathrm{M}, 7 \mathrm{~F}$ & $37.7(30-45)$ & 72 & RTS, IKDC, Brittberg-Peterson, \\
\hline Zaffagnini et al. [37] & $\begin{array}{l}\text { Knee Surgery Sports } \\
\text { Traumatology \& } \\
\text { Arthroscopy }\end{array}$ & 2019 & IV & 31 & $31 \mathrm{M}$ & $22.6(N R)$ & 120 & RTS, IKDC, Tegner \\
\hline Zak et al. [38] & $\begin{array}{l}\text { American Journal of } \\
\text { Sports Medicine }\end{array}$ & 2012 & IV & 70 & $51 \mathrm{M}, 19 \mathrm{~F}$ & $34.9(18-55)$ & 60 & RTS, KOOS, Noyes, Tegner \\
\hline
\end{tabular}

LOE level of evidence, NR not reported, $M$ male, $F$ female, No number, RTS return to sport, KOOS knee injury and osteoarthritis outcome score, SF-36 short-form-36 health survey questionnaire, SF-12 short-form-12 health survey questionnaire, IKDC international knee documentation committee, ICRS international cartilage repair society, EQ-VAS EuroQuol visual analogue scale, WOMAC western Ontario and McMaster universities osteoarthritis index, HSS hospital for special surgery, Mod modified

(69.3\%), followed by OAT (62.3\%), osteochondral allograft (57.1\%) and microfracture (55.1\%), and lowest rates were seen following ACI $(42.7 \%)(p<0.001)$ (Fig. 3).

There were eight studies which reported the mean time to return to sports. The mean time to return to sport was 7.4 months $( \pm 2.9)$, although this was only reported for OAT (four studies), allograft (three studies), and microfracture (one study).

\section{Secondary outcomes}

\section{Patient reported outcome measures}

At final follow up the mean Lysholm score was $84.4 \%$ ( \pm 7.6) and had a weak, positive correlation with return to sport rate $(r=0.52, p<0.001)$. The highest Lysholm scores were seen following OAT $(93.2 \% \pm 0.9)$, followed by MACI $(86.8 \% \pm 4.2)$, microfracture $(81.85 \% \pm 5.0)$, ACI $(81.6 \pm 3.2)$, and osteochondral allograft $(64.0 \% \pm$ 18). The overall mean Tegner score at final follow up was $4.84( \pm 1.37)$. The mean Tegner scores were $6.1( \pm$ $0.5)$ following OAT, $5.4( \pm 0.5)$ following microfracture, 4.9 ( \pm 1.2$)$ following MACI, $4.5( \pm 2.1)$ following osteochondral allograft, and $4.0( \pm 1.5)$ following ACI. There was a weak, positive correlation between rate of return to sport and mean Tegner score at final follow up $(r=$ 0.336, $p<0.001)$. Mean IKDC score overall was 75.2. Highest scores were observed following MACI $(87.3 \pm$

Table 2 Patient demographics from the included studies

\begin{tabular}{|c|c|c|c|c|c|c|c|}
\hline & MFX & $\mathrm{ACl}$ & MACI & OAT & Allograft & PRP + PBSC & Overall \\
\hline Studies & 5 & 6 & 7 & 8 & 4 & 1 & $29^{a}$ \\
\hline Patients (n) & 201 & 240 & 347 & 271 & 197 & 20 & 1276 \\
\hline Age in years (SD) & $32.0( \pm 4.5)$ & $33.1( \pm 4.3)$ & $34.9( \pm 4.8)$ & $32.6( \pm 8.5)$ & $29.5( \pm 3.6)$ & $32.7( \pm 7.5)$ & $32.8( \pm 5.7)$ \\
\hline Gender (M/F, \%) & $69 / 31$ & $68 / 32$ & $67 / 33$ & $73 / 27$ & $58 / 42$ & $65 / 35$ & $67 / 33$ \\
\hline BMl & NR & $24.3( \pm 0.5)$ & $26.1( \pm 0.8)$ & $25.0( \pm 2.5)$ & $25.0( \pm 0.6)$ & $26.0( \pm 2.7)$ & $25.3( \pm 1.0)$ \\
\hline Follow up in months (SD) & $114.1( \pm 51.8)$ & $71.8( \pm 15.9)$ & $65.5( \pm 17.1)$ & $136.5( \pm 47.9)$ & $71.9( \pm 0.3)$ & $61.2(N R)$ & $88.8( \pm 42.4)$ \\
\hline $\begin{array}{l}\text { Preoperative duration of symptoms } \\
\text { in months (SD) }\end{array}$ & $N R$ & $32.9( \pm 5.1)$ & $94.6( \pm 15.3)$ & NR & $58.4( \pm 1.0)$ & 4.3 (NR) & $71.9( \pm 28.1)$ \\
\hline Preoperative mean Tegner score (SD) & $3.2(\mathrm{NR})$ & $3.50( \pm 1.3)$ & $1.9( \pm 0.5)$ & $2.9( \pm 0.0)$ & NR & $N R$ & $2.5( \pm 0.7)$ \\
\hline Preoperative mean Lysholm score (SD) & $50.7( \pm 5.7)$ & $40.5( \pm 0.4)$ & $53.8( \pm 6.9)$ & $64.7( \pm 5.2)$ & $41.0( \pm 13.0)$ & NR & $52.7( \pm 9.3)$ \\
\hline $\begin{array}{l}\text { Preoperative mean IKDC subjective } \\
\text { score (SD) }\end{array}$ & $44.5( \pm 2.8)$ & $41.3(1.4)$ & $40.3( \pm 13.4)$ & $34.8( \pm 13.5)$ & $38.0( \pm 12.0)$ & $50.5( \pm 6.3)$ & $42.1( \pm 4.0)$ \\
\hline \multicolumn{8}{|l|}{ Chondral defects } \\
\hline Size in $\mathrm{cm}^{2}$ (SD) & $3.5( \pm 0.7)$ & $4.0( \pm 1.4)$ & $3.6( \pm 1.2)$ & $2.4( \pm 0.5)$ & $4.5( \pm 1.8)$ & NR & $3.4( \pm 1.2)$ \\
\hline MFC (n) & 99 & 120 & 187 & 155 & 9 & NR & 570 \\
\hline LFC (n) & 37 & 37 & 74 & 54 & 6 & NR & 217 \\
\hline Trochlea (n) & 13 & 18 & 14 & 16 & 21 & 9 & 90 \\
\hline Patella (n) & 7 & 68 & 11 & 4 & 12 & 6 & 108 \\
\hline
\end{tabular}

NR not reported; MFX microfracture, $A C l$ autologous chondrocyte implantation, $M A C I$ matrix-induced autologous chondrocyte implantation, $O A T$ osteochondral autograft transfer, PRP platelet-rich plasma, PBSC peripheral blood stem cells, $M$ male, $F$ female, IKDC international knee documentation committee, MFC medial femoral condyle, LFC lateral femoral condyle. ${ }^{\text {T}}$ Two studies compared more than one biologic technique 


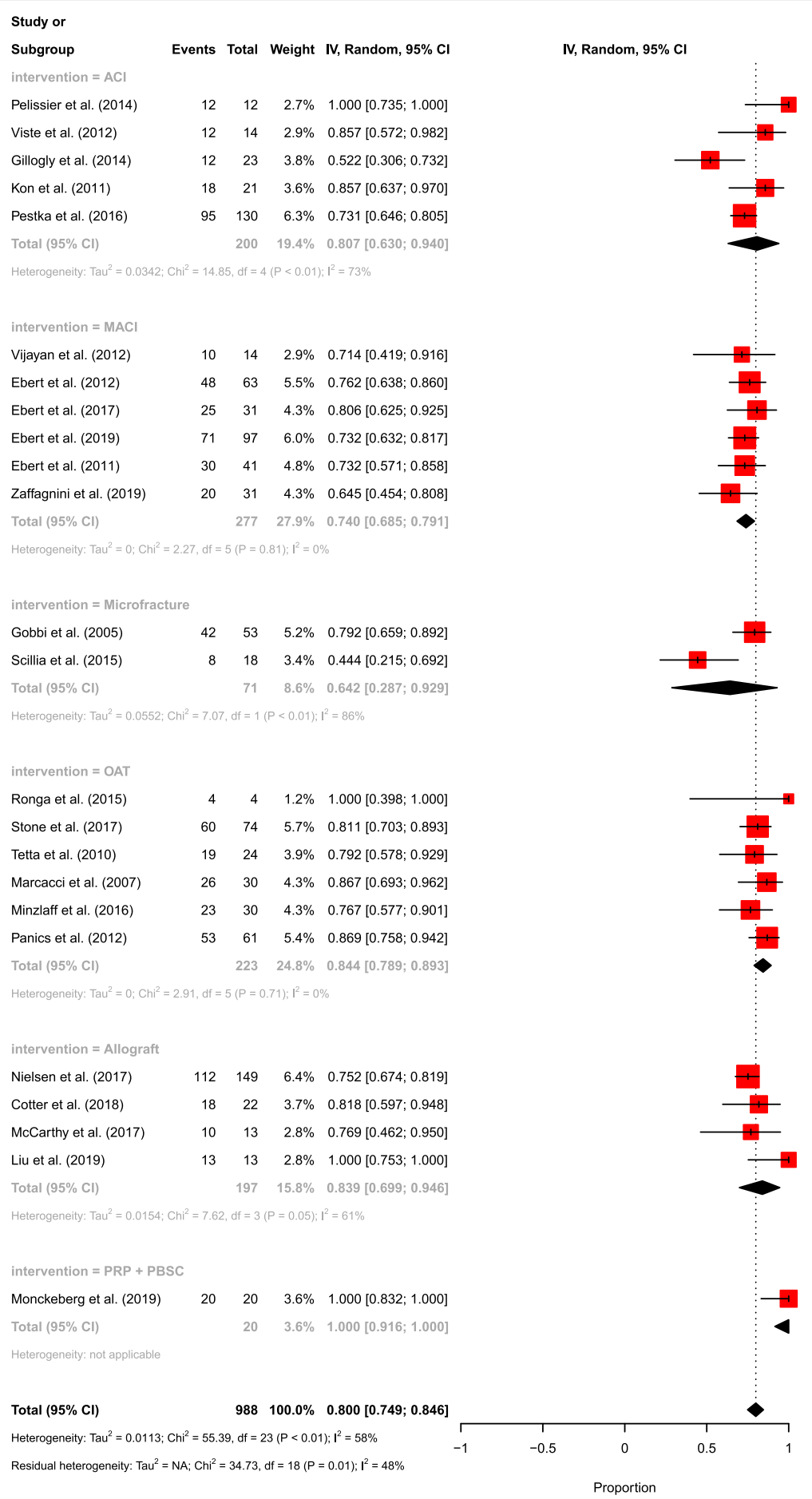

Fig. 2 Forest plot comparing each surgical intervention and the rate of returning to sport

13.6), followed by ACI $(78.5 \pm 8.7)$, PRP and PBSC (72.2 \pm 13.3$)$, OAT (71.7 \pm 18.8$)$, microfracture (71.0 \pm $0.6)$, and osteochondral allograft $(63.0 \pm 22.0)$. There was no correlation between return to sport and either IKDC or KOOS scores $(r=-0.238, p=0.002$; and $r=0.179$, $p=0.005$ respectively).

\section{Previous \& concurrent operations}

There were $64.3 \%$ of patients who had undergone at least one previous surgery on their affected knee prior to the current biologic intervention. This was highest in those undergoing osteochondral allograft (88.6\%), whilst patients undergoing microfracture had the lowest 


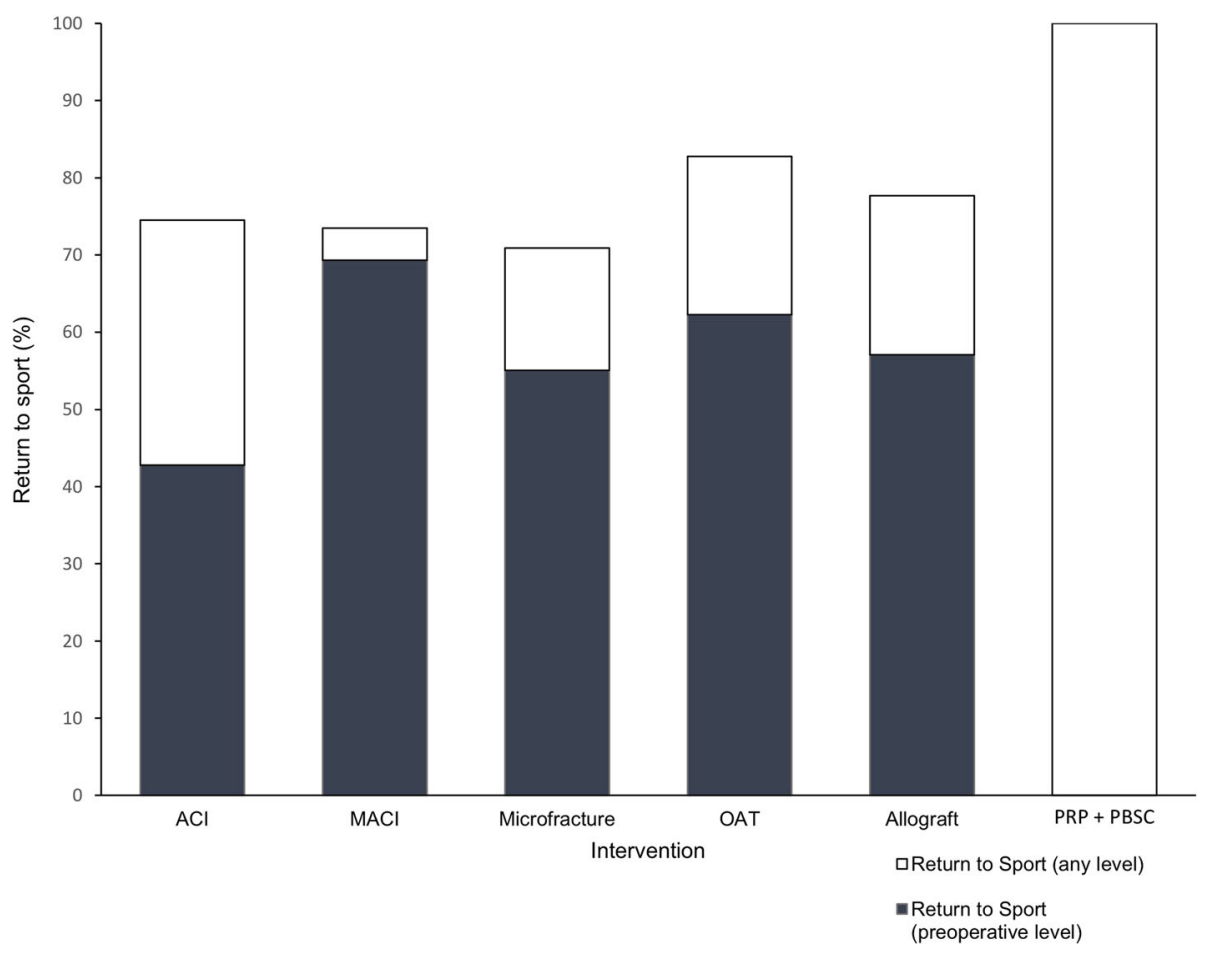

Fig. 3 Proportion of patients returning to sport and returning to the same preoperative level of sport

proportion of previous surgeries (25\%). Concomitant procedures were performed alongside $35.6 \%$ of the operations. This was highest in ACI (69.0\%) and OAT (66.4\%). No patients in the PRP and PBSC group underwent any previous or additional procedures.

\section{Lesion size}

The mean size of chondral lesions was reported in 22 studies and the mean lesion area was $3.4 \mathrm{~cm}^{2}( \pm 1.2)$ (Table 2). A weak, negative correlation between lesion size and return to any level of sport was observed $(r=-$ $0.408, p<0.001)$. No significant differences in lesion size between intervention groups were observed $(p=0.131)$.

\section{Discussion}

This is the first systematic review and meta-analysis to assess the post-operative sporting participation in patients who have undergone biologic intervention for chondral knee defects at mid-term follow up. There is a high rate of sustained return to sport observed following surgery, with relatively worse outcomes for those who have undergone microfracture compared to other modes of intervention.

The sporting participation rate of $80 \%$ is similar to a previous meta-analysis of return to sport following biologic chondral intervention, which found a $76 \%$ return to sport at a much shorter mean follow up of 47 months [19]. Mithoefer et al. also performed a similar meta- analysis with mean follow up of 42 months and found rates of return to sport of $79 \%$ [24]. Our findings that sporting participation was highest following OAT and lowest following microfracture also align with those by Krych et al [19], although the authors found higher rates of returning sport in their study following OAT compared to the present study (92.9\% vs $84.4 \%)$ albeit with shorter follow up. Krych et al found slightly lower rates of returning to sport following microfracture compared to the current study (57.6\% and $64.2 \%$ respectively). Mithoefer et al. also found microfracture to yield the worst rates of returning to sport (68\%) [24]. We additionally reported individual return to sport rates following $\mathrm{ACI}$ and MACI. We showed ACI to have higher rates of sporting participation (80.7\%) compared to MACI $(74.0 \%, p=0.017)$. However, more patients returned to preoperative performance levels following MACI compared to ACI (69.3\% vs $42.7 \%, p<0.001)$.

The highest rates of sporting participation were seen following OAT $(82.8 \%)$ with $62.3 \%$ of patients returning to their preoperative sports performance. Microfracture resulted in the worst rates of return to sport with $64.2 \%$, which was substantially lower than other treatment options. Only one study reported on PRP and PBSC, with all 20 of its patients returning to sport, although it did not specify to which level. MACI reported the highest rate of return to the same preoperative sports level (69.3\%). Overall, almost half of patients in this study 
were not continuing to participate at the same level of sport. However, with a mean age of 32.8 and a mean follow up of 7.4 years this decline of sporting activity may be explained by increasing age. This is the first systematic review to analyse the level of sport that athletes had returned to at mid-term follow up after chondral surgery of the knee. In contrast, Gobbi et al. [13] found that their observed decrease in return to sport was more likely in those with larger or multiple cartilage lesions, suggesting that knee-related factors may also play a role. Additionally, Gudas et al. found a significantly greater decrease in return to sport rates during the postoperative period following microfracture than following OAT [14]. Kon et al. reported similar findings with a decrease in long-term sports participation in their microfracture group in comparison with ACI [17].

The primary limitations of this review were regarding the heterogeneity of the literature and poor quality of some level four studies. Studies reported on a variety of different sports, with varying functional demands. This variation could account, in part, for differences in rates of return to sport. Additionally, there was no common definition for what constituted a return to sport; most papers analysed a return to any level of sport, but some exclusively assessed attainment of preoperative performance levels. Since the sporting objectives for the studies assessing return to preoperative levels of sport were not comparable to those reporting on return to any level, these papers were analysed separately. Some studies assessed professional athletes, some amateur, and some had a mixed population. This difference may account for variation in return to sport rates, particularly regarding return to preoperative performance level.

Furthermore, despite the influence rehabilitation has on the outcomes of cartilage preserving surgery within the knee [5], we could not take this into consideration in the random effects model analysis due to heterogenous reporting of protocols amongst studies. Finally, there was some variation in lesion size amongst the groups, however this was not statistically significant. OAT was typically used for smaller sized lesions, which may reflect a less severe injury to the knee and lead to faster and improved rates of return to sport. Concomitant procedures and previous surgeries were also confounding variables which may have affected patient outcome, for example a simultaneous ACL reconstruction. In contrast, the study measuring PRP and PBSC reported no concomitant procedures which may reflect a more benign knee injury and hence high levels of sporting participation postoperatively.

\section{Conclusion}

A substantial number of patients continue to participate in sport at long term follow up following biologic interventions for chondral defects of the knee. Surgeons should be aware of the poorer rates of sporting participation at mid-term when using microfracture. OAT should be considered for athletes seeking to benefit from sustained future involvement in sport while MACI may achieve the highest probability of returning to the same level of sport prior to injury.

\section{Supplementary information}

Supplementary information accompanies this paper at https://doi.org/10 1186/s40634-020-00295-x.

\section{Additional file 1.}

\section{Abbreviations}

NR: Not reported; MFX: Microfracture; ACl: Autologous chondrocyte implantation; MACl: Matrix-induced autologous chondrocyte implantation; OAT: Osteochondral autograft transfer; PRP: Platelet-rich plasma;

PBSC: Peripheral blood stem cells; KOOS: Knee injury and osteoarthritis outcome score; SF-36: Short form 36; IKDC: International knee documentation committee; SF-12: Short form 12; EQ-VAS: EQ visual analogue scale; WOMAC: Western Ontario and McMaster universities osteoarthritis index

Acknowledgements

Not applicable.

\section{Authors' contributions}

PG Robinson - Study idea, data collection, data analysis, manuscript writing. TR Williamson - data collection, data analysis, manuscript writing. IR Murray manuscript writing, K Al-Hourani - manuscript writing. TO White - manuscript writing. All authors read and approved the final manuscript.

\section{Funding}

Nothing to declare.

\section{Availability of data and materials}

All data generated or analysed during this study are included in this published article [and its supplementary information files].

Ethics approval and consent to participate

Not applicable.

Consent for publication

Not applicable.

\section{Competing interests}

"The authors declare that they have no competing interests"

\section{Author details}

${ }^{1}$ Edinburgh Orthopaedics, Royal Infirmary of Edinburgh, Edinburgh, Scotland. University of Edinburgh Medical School, Edinburgh, Scotland.

Received: 26 August 2020 Accepted: 23 September 2020

Published online: 06 October 2020

\section{References}

1. Arøen A, Løken S, Heir S, Alvik E, Ekeland A, Granlund OG et al (2004) Articular cartilage lesions in 993 consecutive knee arthroscopies. Am J Sports Med 32(1):211-215. https://doi.org/10.1177/0363546503259345

2. Chow JC, Hantes ME, Houle JB, Zalavras CG (2004) Arthroscopic autogenous osteochondral transplantation for treating knee cartilage defects: a 2- to 5year follow-up study. Arthroscopy 20(7):681-690. https://doi.org/10.1016/j. arthro.2004.06.005

3. Cotter EJ, Frank RM, Wang KC, Totlis T, Poland S, Meyer MA et al (2018) Clinical outcomes of Osteochondral allograft transplantation for secondary treatment of Osteochondritis Dissecans of the knee in skeletally mature 
patients. Arthroscopy 34(4):1105-1112. https://doi.org/10.1016/j.arthro.2017. 10.043

4. Curl WW, Krome J, Gordon ES, Rushing J, Smith BP, Poehling GG (1997) Cartilage injuries: a review of 31,516 knee arthroscopies. Arthroscopy 13(4): 456-460. https://doi.org/10.1016/s0749-8063(97)90124-9

5. Della Villa S, Kon E, Filardo G, Ricci M, Vincentelli F, Delcogliano M et al (2010) Does intensive rehabilitation permit early return to sport without compromising the clinical outcome after arthroscopic autologous chondrocyte implantation in highly competitive athletes? Am J Sports Med 38(1):68-77

6. Drongowski RA, Coran AG, Wojtys EM (1994) Predictive value of meniscal and chondral injuries in conservatively treated anterior cruciate ligament injuries. Arthroscopy 10(1):97-102. https://doi.org/10.1016/s07498063(05)80299-3

7. Ebert JR, Fallon M, Smith A, Janes GC, Wood DJ (2015) Prospective clinical and radiologic evaluation of patellofemoral matrix-induced autologous chondrocyte implantation. Am J Sports Med 43(6):1362-1372. https://doi. org/10.1177/0363546515574063

8. Ebert JR, Fallon M, Zheng MH, Wood DJ, Ackland TR (2012) A randomized trial comparing accelerated and traditional approaches to postoperative weightbearing rehabilitation after matrix-induced autologous chondrocyte implantation: findings at 5 years. Am J Sports Med 40(7):1527-1537. https:// doi.org/10.1177/0363546512445167

9. Ebert JR, Robertson WB, Woodhouse J, Fallon M, Zheng MH, Ackland T et al (2011) Clinical and magnetic resonance imaging-based outcomes to 5 years after matrix-induced autologous chondrocyte implantation to address articular cartilage defects in the knee. Am J Sports Med 39(4):753-763. https://doi.org/10.1177/0363546510390476

10. Ebert JR, Smith A, Janes GC, Wood DJ (2019) Association between isokinetic knee strength and perceived function and patient satisfaction with sports and recreational ability after matrix-induced autologous chondrocyte implantation. Orthopaedic J Sports Med. https://doi.org/10.1177/ 2325967119885873

11. Gillogly SD, Arnold RM (2014) Autologous chondrocyte implantation and anteromedialization for isolated patellar articular cartilage lesions: 5- to 11year follow-up. Am J Sports Med 42(4):912-920. https://doi.org/10.1177/ 0363546513519077

12. Gobbi A, Karnatzikos G, Kumar A (2014) Long-term results after microfracture treatment of full-thickness knee chondral lesions in athletes. Knee Surg Sports Traumatol Arthrosc 22:1986-1996. https://doi.org/10.1007/ s00167-013-2676-8

13. Gobbi A, Nunag P, Malinowski K (2005) Treatment of full thickness chondral lesions of the knee with microfracture in a group of athletes. Knee Surg Sports Traumatol Arthrosc 13(3):213-221. https://doi.org/10.1007/s00167004-0499-3

14. Gudas R, Gudaite A, Pocius A, Gudiene A, Cekanauskas E, Monastyreckiene E et al (2012) Ten-year follow-up of a prospective, randomized clinical study of mosaic osteochondral autologous transplantation versus microfracture for the treatment of osteochondral defects in the knee joint of athletes. Am J Sports Med 40(11):2499-2508. https://doi.org/10.1177/0363546512458763

15. Keng A, Sayre EC, Guermazi A, Nicolaou S, Esdaile JM, Thorne A et al (2017) Association of body mass index with knee cartilage damage in an asymptomatic population-based study. BMC Musculoskelet Disord 18(1):517. https://doi.org/10.1186/s12891-017-1884-7

16. Kon E, Filardo G, Berruto M, Benazzo F, Zanon G, Della Villa S et al (2011) Articular cartilage treatment in high-level male soccer players: a prospective comparative study of arthroscopic second-generation autologous chondrocyte implantation versus microfracture. Am J Sports Med 39(12): 2549-2557. https://doi.org/10.1177/0363546511420688

17. Kon E, Filardo G, Di Martino A, Patella S, D'Orazio L, Marcacci M (2011) Arthroscopic autologous chondrocyte transplantation - prospective study: results at minimum 7 years follow-up. Arthroscopy 27(10):e181-e182. https://doi.org/10.1016/j.arthro.2011.08.166

18. Kon E, Gobbi A, Filardo G, Delcogliano M, Zaffagnini S, Marcacci M (2009) Arthroscopic second-generation autologous chondrocyte implantation compared with microfracture for chondral lesions of the knee: prospective nonrandomized study at 5 years. Am J Sports Med 37(1):33-41. https://doi. org/10.1177/0363546508323256

19. Krych AJ, Pareek A, King AH, Johnson NR, Stuart MJ, Williams RJ 3rd (2017) Return to sport after the surgical management of articular cartilage lesions in the knee: a meta-analysis. Knee Surg Sports Traumatol Arthrosc 25(10): 3186-3196. https://doi.org/10.1007/s00167-016-4262-3

20. Liu JN, Agarwalla A, Garcia GH, Christian DR, Gowd AK, Yanke AB et al (2019) Return to sport and work after high Tibial osteotomy with concomitant medial meniscal allograft transplant. Arthroscopy 35(11):30903096. https://doi.org/10.1016/j.arthro.2019.05.053

21. Marcacci M, Kon E, Delcogliano M, Filardo G, Busacca M, Zaffagnini S (2007) Arthroscopic autologous osteochondral grafting for cartilage defects of the knee: prospective study results at a minimum 7-year follow-up. Am J Sports Med 35(12):2014-2021. https://doi.org/10.1177/0363546507305455

22. McCarthy MA, Meyer MA, Weber AE, Levy DM, Tilton AK, Yanke AB et al (2017) Can competitive athletes return to high-level play after Osteochondral allograft transplantation of the knee? Arthroscopy 33(9): 1712-1717. https://doi.org/10.1016/j.arthro.2017.03.020

23. Minzlaff P, Feucht MJ, Saier T, Cotic M, Plath JE, Imhoff AB et al (2016) Can young and active patients participate in sports after osteochondral autologous transfer combined with valgus high tibial osteotomy? Knee Surg Sports Traumatol Arthrosc 24(5):1594-1600. https://doi.org/10.1007/ s00167-014-3447-x

24. Mithoefer K, Della Villa S (2012) Return to sports after articular cartilage repair in the football (soccer) player. Cartilage 3(1):s57-s62. https://doi.org/ $10.1177 / 1947603511410419$

25. Monckeberg JE, Rafols C, Apablaza F, Gerhard P, Rosales J (2019) Intraarticular administration of peripheral blood stem cells with platelet-rich plasma regenerated articular cartilage and improved clinical outcomes for knee chondral lesions. Knee 26(4):824-831. https://doi.org/10.1016/j.knee. 2019.05.008

26. Nielsen ES, McCauley JC, Pulido PA, Bugbee WD (2017) Return to sport and recreational activity after Osteochondral allograft transplantation in the knee. Am J Sports Med 45(7):1608-1614. https://doi.org/10.1177/ 0363546517694857

27. Ollat D, Lebel B, Thaunat M, Jones D, Mainard L, Dubrana F et al (2011) Mosaic osteochondral transplantations in the knee joint, midterm results of the SFA multicenter study. Orthop Traumatol Surg Res 97(8 Suppl):s160s166. https://doi.org/10.1016/j.otsr.2011.08.005

28. Panics G, Hangody LR, Balo E, Vasarhelyi G, Gal T, Hangody L (2012) Osteochondral autograft and Mosaicplasty in the football (soccer) athlete. Cartilage 3(1):s25-s30. https://doi.org/10.1177/1947603511408286

29. Pelissier A, Boyer P, Boussetta Y, Bierry G, Van Hille W, Hamon P et al (2014) Satisfactory long-term MRI after autologous chondrocyte implantation at the knee. Knee Surg Sports Traumatol Arthrosc 22(9):2007-2012. https://doi. org/10.1007/s00167-013-2428-9

30. Pestka JM, Feucht MJ, Porichis S, Bode G, Sudkamp NP, Niemeyer P (2016) Return to sports activity and work after autologous chondrocyte implantation of the knee: which factors influence outcomes? Am J Sports Med 44(2):370-377. https://doi.org/10.1177/0363546515614578

31. Ronga M, Stissi P, G LAB, Valoroso M, Angeretti G, Genovese E et al (2015) Treatment of unstable osteochondritis dissecans in adults with autogenous osteochondral grafts (Mosaicplasty): long-term results. Joints 3(4):173-178. https://doi.org/10.11138/jts/2015.3.4.173

32. Scillia AJ, Aune KT, Andrachuk JS, Cain EL, Dugas JR, Fleisig GS et al (2015) Return to play after chondroplasty of the knee in National Football League athletes. Am J Sports Med 43(3):663-668. https://doi.org/10.1177/ 0363546514562752

33. Stone KR, Pelsis JR, Na K, Walgenbach AW, Turek TJ (2017) Articular cartilage paste graft for severe osteochondral lesions of the knee: a 10- to 23-year follow-up study. Knee Surg Sports Traumatol Arthrosc 25(12):3824-3833. https://doi.org/10.1007/s00167-016-4323-7

34. Tetta C, Busacca M, Moio A, Rinaldi R, Delcogliano M, Kon E et al (2010) Knee osteochondral autologous transplantation: long-term MR findings and clinical correlations. Eur J Radiol 76(1):117-123. https://doi.org/10.1016/j. ejrad.2009.05.011

35. Vijayan S, Bartlett W, Bentley G, Carrington RW, Skinner JA, Pollock RC et al (2012) Autologous chondrocyte implantation for osteochondral lesions in the knee using a bilayer collagen membrane and bone graft: a two- to eight-year follow-up study. J Bone Joint Surg (Br) 94(4):488-492. https://doi. org/10.1302/0301-620X.94B4.27117

36. Viste A, Piperno M, Desmarchelier R, Grosclaude S, Moyen B, Fessy MH (2012) Autologous chondrocyte implantation for traumatic full-thickness cartilage defects of the knee in 14 patients: 6-year functional outcomes. 
Orthop Traumatol Surg Res 98(7):737-743. https://doi.org/10.1016/j.otsr. 2012.04.019

37. Zaffagnini S, Vannini F, Di Martino A, Andriolo L, Sessa A, Perdisa F et al (2019) Low rate of return to pre-injury sport level in athletes after cartilage surgery: a 10-year follow-up study. Knee Surg Sports Traumatol Arthrosc 27(8):2502-2510. https://doi.org/10.1007/s00167-018-5255-1

38. Zak L, Aldrian S, Wondrasch B, Albrecht C, Marlovits S (2012) Ability to return to sports 5 years after matrix-associated autologous chondrocyte transplantation in an average population of active patients. Am J Sports Med 40(12):2815-2821. https://doi.org/10.1177/0363546512462382

\section{Publisher's Note}

Springer Nature remains neutral with regard to jurisdictional claims in published maps and institutional affiliations.

\section{Submit your manuscript to a SpringerOpen ${ }^{\circ}$ journal and benefit from:}

- Convenient online submission

Rigorous peer review

- Open access: articles freely available online

High visibility within the field

- Retaining the copyright to your article

Submit your next manuscript at $\boldsymbol{\nabla}$ springeropen.com 